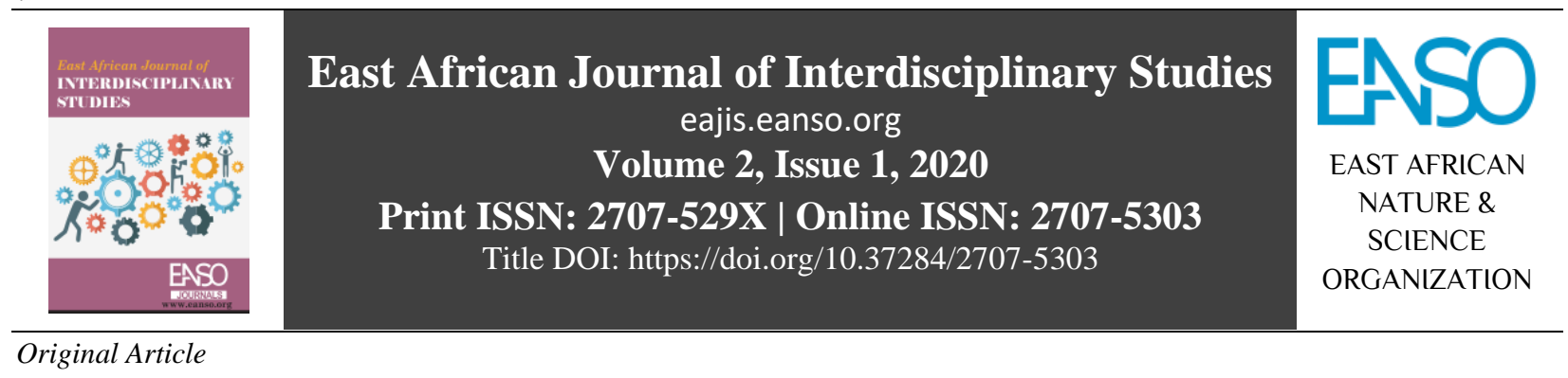

\title{
Community Policing: An approach for Countering Youth Radicalization in Eastleigh Area of Nairobi County
}

\author{
Mike Kiplagat Chepkong'a, $P h D^{1^{*}}$ \\ ${ }^{1}$ University of Nairobi, Main Campus; P. O. Box 30197 - 00100, Nairobi Kenya. \\ *Author for Correspondence Email: mkonga@uonbi.ac.ke
}

Article DOI: https://doi.org/10.37284/eajis.2.1.212

\section{Date Published: ABSTRACT}

11 September 2020 Community policing approaches have been used successfully to prevent crime, reduce the fear of crime, and improve public safety. A raging debate, however,

Keywords: is emerging as to whether this approach can be used with equal effectiveness in the prevention of terrorism. Over the last sixteen years, Kenya has tried

Community Policing, Radicalization,

Policing,

Youths. several approaches to "the war against terrorism." However, none of the approaches has succeeded in stamping out terrorism. The purpose of this study, therefore, was to find out ways in which the philosophy of community policing could be modelled to fit a citizen based-counter terrorism strategy. The study established that community policing principles can be used to create sustainable partnerships between law enforcement agencies and residents, thus facilitating the identification of root causes of youth radicalization. Training of police officers on community policing principles and trends in youth radicalization was strongly recommended. Further, police officers should invest more in trust-building initiatives in establishing a joint early warning system with the local communities they serve. The study further recommends an intensive public awareness campaign on the nature, indicators, and symptoms of youth radicalization within Eastleigh and the country at large.

\section{APA CITATION}

Chepkong'a, M. (2020). Community Policing: An approach for Countering Youth Radicalization in Eastleigh Area of Nairobi County. East African Journal of Interdisciplinary Studies, 2(1), 89-99. https://doi.org/10.37284/eajis.2.1.212

\section{CHICAGO CITATION}

Chepkong'a, Mike. 2020. "Community Policing: An approach for Countering Youth Radicalization in Eastleigh Area of Nairobi County”. East African Journal of Interdisciplinary Studies 2 (1), 89-99. https://doi.org/10.37284/eajis.2.1.212.

\section{HARVARD CITATION}

Chepkong'a, M. (2020) "Community Policing: An approach for Countering Youth Radicalization in Eastleigh Area of Nairobi County”, East African Journal of Interdisciplinary Studies, 2(1), pp. 89-99. doi: 10.37284/eajis.2.1.212. 
IEEE CITATION

M. Chepkong'a, "Community Policing: An approach for Countering Youth Radicalization in Eastleigh Area of Nairobi County", EAJIS, vol. 2, no. 1, pp. 89-99, Sep. 2020.

\section{MLA CITATION}

Chepkong'a, Mike. "Community Policing: An approach for Countering Youth Radicalization in Eastleigh Area of Nairobi County”. East African Journal of Interdisciplinary Studies, Vol. 2, no. 1, September 2020, pp. 89-99, doi:10.37284/eajis.2.1.212.

\section{INTRODUCTION}

In Eastern Africa, radicalization is increasingly gaining international attention. This is evidenced by the rampant occurrence of terrorist activities mainly by youths of Somali origin. Somalia has made international headlines for almost two decades now; first, as a place of the civil war characterized by clan warfare and humanitarian catastrophe, then as a failed state, and finally as a potential safe haven for Islamist terrorists (Marchal and Roland, 2009). Trusting partnerships between the police and local citizens are the cornerstone of community policing.

The engagement of various community groups within Eastleigh on a broad array of public safety is likely to motivate the local communities to address their own security concerns. Assured of improved quality-of-life, the residents are likely to be encouraged to own a local process that focuses on the factual causes of radicalization. In addition, community policing initiatives are likely to take cognizance of the various subsets of the population that form a community, with emphasis on the different security needs that each of the values most. The purpose of this study, therefore, was to explore the role of community policing in countering radicalization within the Eastleigh area in Nairobi County. The objective of the study was to identify risk factors that drive youth to radicalization; to establish the typical characteristics, features and behavioural patterns of radicalized youth and related activities; to establish how principles of community policing can assist in the identification of radicalized youth, and to elicit suggestions on how to solve the problem of youth radicalization within Eastleigh area.

\section{Problem Statement}

Globally, the task of countering terrorism is largely the domain of security agencies to expedite various security services. These systems seek to achieve security mainly through 'hard power' tools, with no or little collaboration with civilians. Numerous research findings on the effects of 'hard' strategies on counter-terrorism exist, there is very little literature on the involvement of local communities in addressing the threat of youth radicalization. For instance, Mogire and Mkutu Agade (2011) researched on counter-terrorism in Kenya with specific regard to the effectiveness of the terrorism control measures the government had put in place. Further, Aronson (2012) only concentrated on the participation of the Muslim community in countering terrorism across the country in general. This study, therefore, sought to establish the feasibility of police-public partnerships in addressing risk factors that predispose youth to radicalization within the Kenya context. Premised on mutual interest and trust, such partnerships are likely to promote a common understanding of the causes and drivers of youth radicalization within Eastleigh.

\section{Theoretical Framework}

This study uses the frustration-aggression theory proposed by Dollard et al. (1939) to explain the frustration that arises as a result of blocking or frustrating a person's efforts to attain a goal or an objective. This theory suggests that terrorist behaviour arises because of the frustration related to political and economic situations. The political and economic climates that foster such frustration are actually years of alienation and marginalization, a condition that invokes the need to initiate and drive change in a radical way.

\section{METHODOLOGY}

\section{Study site}

The study was carried out in the Eastleigh area of Nairobi County, Kenya. As the capital city of the country, Nairobi is booming in various dimensions and is the seat of the National Government with various international agencies' headquarters. 
Eastleigh area has a population of 174,349 , most of whom were refugees back to the early 1990s triggered by insecurity in Somalia, Ethiopia, and the Great Lakes region. According to UNHCR and Danish Refugee Council (2012), Asylum seekers and refugees from Somalia are the most populous followed by a sizeable Ethiopian Oromo community and a minority from the Great Lakes, Eritrea, and South Sudan. Eastleigh is, therefore, the preferred location for Somalis migrating to Nairobi.

\section{Research Design}

Structured survey questionnaire was utilized to collect quantitative data. While qualitative data was collected through interviewing key respondent and conducting group discussions. Basically, this involves qualitative in-depth interviews with people who know what is going on in the community. An interview schedule is a plan or a guide for an investigation into a particular subject matter. The study adopted a descriptive survey design, an approach that helps to describe characteristics of a population or phenomenon (Kombo and Tromp, 2010).

The target population comprised the national police officers and civilians from welfare and entrepreneurship groups, as well as community policing committees. Primary respondents were picked through systematic random sampling. Due to the heterogeneous nature of the community population, a $30 \%$ sample size was considered appropriate. Subsequently, the study identified a sample frame of twenty - two (22) community groups, each. Eight (8) respondents from each of the twenty-two (22) groups gave a total of 176 primary respondents. Police respondents included three senior police commanders drawn from the Divisional police command.

\section{RESULTS}

\section{Demographic Characteristics of Respondents}

About $48 \%$ of the community-group membership were aged 41 to 50 years. No single community group had members aged below 18 years. Those aged over 60 years were a paltry $5 \%$. The implication here is that Eastleigh residents who join community groups are mainly those aged between
31 and 60 years. A substantial proportion of respondents are able to read and write. Formal education was therefore quantified as an estimation of respondents' cognitive skills as far as knowledge on radicalization is concerned in the $21^{\text {st }}$ Century are concerned. Most of the respondents had attained secondary education $(78,52 \%) ; 31(21.8 \% 0 \mathrm{had}$ primary education; $7(4.8 \%)$ has at least college or university education while $40(20.4 \%)$ had attained other levels of education.

More than $95 \%$ of the respondents had resided in Eastleigh for a period exceeding five years. Though, there was a notable $12.2 \%$ who had been Eastleigh habitats for over thirty consecutive years, with only $2 \%$ having stayed in the area for less than one year. Interview with key community informants revealed that most of the residents who had stayed for over thirty years had Eastleigh as their permanent homes. In the view of the foregoing, it is highly probable that the target population has had any interaction with Eastleigh environment that may qualify them to make reasonable observations with regard to youth proselytization to violent extremism.

Respondents' religion was: $68.7 \%$ Christians, 27.9\% Muslims while others 3.4\%. According to Vittori and Bremer (2009), Muslims comprise a little more than 11 percent of all the people living in Kenya. The NCPD (2013) places Kenya Population at slightly above 46 million. Large concentrations of Kenyan Muslims live in Coast and North Regions, and the capital city of Nairobi, and Eastleigh in particular.

\section{Youth Radicalization Risk Factors}

This section covers an in-depth analysis of various factors that may directly or indirectly prompt youth into radicalization. These factors were poverty, low level of education, religious fanatism, political discrimination, lack of employment, breakdown of social values, historical injustices, economic marginalization, search for self-identification and discriminative law enforcement practices. Respondents were asked to indicate the extent to which they thought these factors risked youth to radicalization within the Eastleigh area. As tabulated in Table 1, it can be shown that other than historical injustices and search for identification, all 
other factors had a significant influence on youth radicalization as discussed below:

\section{Poverty, Education Levels and Lack of Employment}

More than half of the respondents felt that poverty (66.7\%), low education levels (76.9\%), lack of employment (68.7\%), and economic marginalization $(60 \%)$ were key causes of youth radicalization in Eastleigh (Table 1). This finding is consistent with Fearon and Laitin (2003), who identified poverty, economic deprivation, and lack of employment as conditions conducive for delinquency. In addition, violent extremist groups tend to target populations afflicted by economic deficiencies and high levels of illiteracy. Further, Allan et al. (2015) opine that the emergence of Islamist violent extremism in Kenya is consistent with the economic situation of the country in general and the youth in particular.

Contrary to this view, studies in Africa have shown that extremist groups often thrive in areas where education is poorest with youth population characterized by poverty and unemployment, particularly North-east Nigeria, northern Kenya, and southern Somalia (Botha, 2014). This finding creates the impression that illiterate people can be more easily manipulated because their state of social deprivation denies them the capacity and knowledge to critically question the narratives and doctrines of extremist groups. On the other hand, over $23 \%$ of the respondents felt that poverty and unemployment did not contribute to youth radicalization. However, this view is contradicted by Botha (2013) who established that Kenyan youth were attracted by higher wages offered by alShabaab recruiters.

\section{Religious Fanatism and Breakdown of Social} values

As presented in Table 1, over $96.6 \%$ of the respondents were of an extreme opinion that religious fanatism was a key driver of youth radicalization within Eastleigh. This view was shared by Rogers et al. (2007), who found that religious identity had a major impact on attitudes and that those youths who held Islam as their primary identity exhibited more positive views towards Jihad and martyrdom. Indeed, a key informant who was a Muslim cleric within Eastleigh disclosed that some Islam preachers were misinterpreting Islamic doctrines to justify recruitment and indoctrination of youth into violent extremism. Further, over $80 \%$ (10 out of 12) of the police interviewees held the view that religion, and especially Islam was the key cause and driver of radicalization. The findings suggest that both the police and the residents of Eastleigh strongly associate religion and particularly Islam, with radicalization to violent extremism. Subsequently, this position limits the focus of youth radicalization to Islam, a perception that is likely to lead to religious conflict between communities living in Eastleigh.

According to Allan et al. (2015), radicalization and terrorism is a multifaceted phenomenon that cannot be reduced to religion as the single causal factor. Terrorism results from a complex array of economic, political, psychological, and social forces the precise mix of which varies from place to place and person to person. The fact that some individuals and groups wrap their justifications in Islamic rhetoric does not qualify Islam as the sole cause and driver of violent radicalization (Allan et al., 2015).

\section{Table 1: Youth Radicalization Factors}

\begin{tabular}{lllllll}
\hline Risk Factors & \multicolumn{2}{c}{ Extremely } & \multicolumn{2}{c}{ Some How } & \multicolumn{2}{c}{ Never } \\
& $\mathbf{n}$ & $\mathbf{\%}$ & $\mathbf{n}$ & $\mathbf{\%}$ & $\mathbf{n}$ & $\mathbf{\%}$ \\
\hline Poverty & 98 & 66.7 & 14 & 9.5 & 35 & 23.8 \\
Low level of education & 113 & 76.9 & 21 & 14.3 & 13 & 8.8 \\
Religious Fanatism & 142 & 96.6 & 3 & 2 & 2 & 1.4 \\
Political discrimination & 72 & 49 & 15 & 10.2 & 60 & 40.8 \\
Lack of employment & 101 & 68.7 & 14 & 9.5 & 32 & 21.8 \\
Breakdown of social values & 88 & 59.9 & 43 & 29.2 & 16 & 10.9 \\
Historical injustices & 44 & 29.9 & 58 & 39.5 & 45 & 30.6 \\
\hline
\end{tabular}


East African Journal of Interdisciplinary Studies, Volume 2, Issue 1, 2020

Article DOI: https://doi.org/10.37284/eajis.2.1.212

\begin{tabular}{lllllll}
\hline Risk Factors & \multicolumn{2}{c}{ Extremely } & \multicolumn{2}{c}{ Some How } & \multicolumn{2}{c}{ Never } \\
& $\mathbf{n}$ & $\mathbf{\%}$ & $\mathbf{n}$ & $\mathbf{\%}$ & $\mathbf{n}$ & $\mathbf{\%}$ \\
\hline Economic marginalization & 88 & 60 & 50 & 34 & 9 & 6 \\
Search for self-identification & 42 & 28.6 & 422 & 8.6 & 63 & 42.8 \\
Discriminative law enforcement practices & 133 & 90.5 & 14 & 9.5 & 0 & 0.0 \\
\hline
\end{tabular}

\section{Discriminative Politics and Law Enforcement}

Discriminative enforcement of the law by the police as well stood out as a key factor driving youth into violent extremism. About $90.5 \%$ of the respondents felt that youths were unfairly targeted during police swoops and operations (Table 1). The results may effectively be interpreted to suggest that blocked or minimal political participation by the youth within Eastleigh may create alienation that can be harnessed to promote violent extremism. This inference is in fact in line with observations made by Schmid (2013), who opine that politicians commonly stoke youth frustrations and promise sweeping reforms aimed at improving their lives. After winning their elections, they may ignore or abandon youth supporters, leaving a semiorganized and politically charged youth cohort idle. Politicians who lose their elections may similarly exploit their youth followers by inciting them to violent protests or armed resistance. In both cases, political manipulation leads young people to feel disillusioned with politicians and electoral politics. This feeling may contribute to the conclusion that solutions to youth problems must be achieved outside of mainstream politics, perhaps through violent extremism.

\section{Behavioural Patterns and Features of Radicalized Youth}

Respondents were presented with a list of observable characteristics that are likely to signify that one is at one stage or another in the cycle of radicalization to violent extremism. The respondents were asked to indicate the extent to which they agreed with these patterns/characteristics. The responses are summarized in Table 2.

Table 2: Features of Radicalized Youth

\begin{tabular}{lllllll}
\hline \multirow{2}{*}{ Behavioural Pattern } & \multicolumn{2}{l}{ Agree } & Neutral & \multicolumn{3}{c}{ Disagree } \\
& $\mathbf{n}$ & $\mathbf{\%}$ & $\mathbf{n}$ & $\mathbf{\%}$ & $\mathbf{n}$ & $\mathbf{\%}$ \\
\hline Concentration on self-image & 84 & 57.1 & 13 & 8.8 & 50 & 34 \\
Newfound patriotism & 127 & 86.4 & 10 & 6.8 & 10 & 6.8 \\
Adverse expression & 100 & 68 & 3 & 2 & 44 & 30 \\
Expressed feelings of disconnection & 75 & 51 & 17 & 11.6 & 55 & 37.4 \\
Disconnect from associates & 133 & 90.5 & 11 & 7.5 & 3 & 2 \\
Aggressive demeanour & 87 & 59.2 & 23 & 15.6 & 37 & 25.2 \\
Sudden travels & 111 & 75.5 & 14 & 9.5 & 22 & 15 \\
Viewing society as enemy & 130 & 88.4 & 8 & 5.4 & 9 & 6.2 \\
Change in physical appearance/attire & 29 & 19.7 & 38 & 25.9 & 80 & 54.4 \\
Acquisition of new religious ideologies & 142 & 96.6 & 0 & 0 & 5 & 3.4 \\
\hline
\end{tabular}

\section{Religion and Social Disconnect}

Out of the 147 respondents, 142(96.6\%) strongly felt that the acquisition of new religious ideologies was a key indicator of youth under the process of radicalization within the Eastleigh area. Indeed, research has shown that religion is pretty a big motivation element and those extremist actions which make for the name of religion are a fundamental danger for societies (Guiro, 2008). According to Ali (2009), religious creeds, though not the only significant indicator of radicalization is becoming one of the predominant models for extremism in the modern world. Consequently, there appears to be a causal connection between belief and behaviour. This is because interviewees 
from Islam and Christian faiths, including those who did not subscribe to any faith were pointing at some Islamic practices as indicators of radicalization. This position is supported by the view of over $40 \%$ of respondents who indicated that those exposed to the process of radicalization adopted the Islamic dress code.

It is imperative to note that radicalization is associated with overt and observable behavioural changes linked to the Islamic ideology. The individual may change their appearance, their health may suffer (including mental health) and they may become isolated from family, friends, peers, or social groups (Guiro, 2008). Accordingly, an inference can duly be drawn to the effect that violent extremists may articulate and justify their agendas using religious language. However, a closer look at the foregoing strongly suggests that religion is not an inherent source of violence, but rather, a channel through which youth radicalization may most effectively be sustained. Similarly, over $90 \%$ of the respondents felt that social disconnect was an observable phenomenon amongst youth being exposed to radicalism (Table 2). According to Diani and McAdam (2003), youth radicalization is directly linked to its social context. Such factors as a perceived moral outrage that affects an individual's sensibility, overt demonstrations of discrimination and exclusion could easily point to targets and victims of radicalization. More than $9.50 \%$ of the respondents indicated that those youth who had been exposed to radicalization would express their dissatisfaction by disconnecting from family members, friends, colleagues, and even spouses (Table 2).

\section{Anti-authority, Aggression and New Found Patriotism}

Over $60 \%$ of the respondents agreed that hostility towards the authorities and aggressive demeanour to the society at large could be a sign that a young person was being radicalized. The implication here is that the recruiters may present themselves as the pseudo-government, providing social services and other support mechanisms, personal, welfare, and social - that might not already be met by their social or familial networks. One of the key informants to the study disclosed that parts of the youth population who are living in poverty, lack shelter and food, and have limited access to education are meant to believe that the society is deliberately unfair to them. This ideology can, therefore, easily create aggressive feelings among the unfortunate youth towards the local community in general.

Most, 127(86.4\%) of the respondents were of the view that youth exposed to radicalism was most likely to pronounce a newfound patriotism. This is irrespective of whether one hails from rich or poor backgrounds. Indeed, a chairperson of a local peace and security committee supposed that even young persons from relatively wealthy backgrounds were not spared either. The interviewee added that those recruited from such backgrounds are likely to adopt antagonistic and hostile demeanour towards their old friends and at the same time exhibit a new sense of identity, prestige, or pride. However, over $54 \%$ of the respondents felt that change in physical appearance or acquisition of a new dress code was not necessarily indicative of young persons under the process of radicalization. Undoubtedly, this was supported by a member of the peace and security committee who emphasized that the al-Shabaab recruiters had devised shrewd techniques of disguising young people that they recruit into extremism. A key respondent familiar with radicalization disclosed that a local school expelled three boys in as many months for displaying conduct that went contrary to school regulations. The assertion revealed that not only male youth are targeted by terrorist operatives. There is a high possibility, therefore, that the terrorist organizations are disguising in Islam to recruit youth irrespective of their race, sex, ethnic, or religious backgrounds.

\section{Information Sharing, Early Warnings, and Police Feedback}

As presented in Table 3, 93.2\%, that is 137 of the total 147 respondents felt that information sharing between the government authorities and the members of the public would be extremely effective in identifying youth radicalization activities within Eastleigh. The same position is held by Botha (2013), who observes that the police have a critical role of engaging with local communities to increase their ability to identify individuals at risk of falling to violent extremism. 
A significant proportion of $90 \%$ of the police commanders that were interviewed felt that terrorism is such a sensitive crime that any information in respect of radicalization to extremism should only be handled within the National intelligence model. Six of commanders at the station and post level emphasized that communication and indeed information management was clearly captured in the Service regulations. Concern was placed on the credibility of information that the local residents are likely to offer. A station commander pointed out that they could not act on information that has not been sanctioned by the Divisional bosses. Although about $15 \%$ of the respondents were of the opinion that early warning platforms would have no effect on vulnerable youth, the majority of them $(68 \%)$ felt that such a system would be extremely effective.

Over $90 \%$ of the respondents felt that timely policepublic feedback is a crucial factor in the prevention of youth radicalization. This finding corroborates Otiso (2009) who opine that some communities may experience discrimination or alienation based on popular stereotypes about the kinds of people responsible for terrorism, or communities that may perceive themselves as being unfairly targeted by law enforcement. Appropriate feedback on police operations to the local communities is highly likely to lessen the burden of suspicion and mistrust associated with the police.

Table 3: Community Policing and Radicalization Activities

\begin{tabular}{lllllll}
\hline & \multicolumn{2}{c}{ Extremely Effective } & \multicolumn{2}{c}{ Slightly effective } & \multicolumn{2}{c}{ No effect } \\
Activity & n & \% & n & \% & n & \% \\
\hline Public -police information sharing & 137 & 93.2 & 8 & 5.4 & 2 & 1.4 \\
Common early warning platform & 100 & 68 & 24 & 16.3 & 23 & 15.6 \\
Monitoring of religious institutions & 141 & 95.9 & 6 & 4.1 & 0 & 0.0 \\
Scrutiny on the nature of training & 96 & 65.3 & 44 & 29.9 & 7 & 4.8 \\
Identification of strangers & 102 & 69.4 & 14 & 9.5 & 31 & 21.1 \\
Reporting youth drug activities & 14 & 9.5 & 15 & 10.2 & 118 & 80.3 \\
Timely public-police feedback & 133 & 90.5 & 13 & 8.8 & 1 & 0.7 \\
Recurring youth problems & 123 & 83.7 & 13 & 8.8 & 11 & 7.5 \\
Disclosing structures & 95 & 64.6 & 41 & 27.9 & 11 & 7.5 \\
Police transparency & 144 & 98 & 3 & 2.0 & 0 & 0.0 \\
Joint rehabilitation programmes & 140 & 95.2 & 7 & 4.8 & 0 & 0.0 \\
\hline
\end{tabular}

Rehabilitation of Ex-Convicts, Illegal Drugs, and Identification of Strangers

As shown in table 3, about $95 \%$, that is 140 of the total respondents felt that joint rehabilitation of exconvicts of radicalism and returnees from terror groups was an effective approach to interdicting youth radicalization in Eastleigh area. As noted by Rosand, Millar and Ipe (2007), a rehabilitation strategy that comprises counselling programs is likely to re-educate violent extremists and extremist sympathizers through intensive objective debates, religious guidance, and psychological counselling. An interviewee who was a Muslim cleric observed that a joint rehabilitation program might dissuade the state from exacting revenge on returnees and is further likely to reinforce a whole range of counternarratives and positive messages. These may include the concept that extremists only use their recruits to advance their own cause and that those who fall in with militants have misunderstood the basic tenets of Islam. He added that he had observed local youths who been incarcerated for six months seeking to re-join the al-Shabaab because those who knew them had already labelled the 'terrorists. The implication here is that a program that is based not on punishment or retribution but on a presumption of benevolence is likely to encourage acceptance of ex-convicts and returnees and develop notions of inclusion.

More than $80 \%$ of the respondents were of the opinion that identifying and reporting youth involvement in illegal drug activities was not a factor in taming youth radicalization. This realization could be interpreted to mean that illegal 
drug activities are either not prevalent within the Eastleigh area or that this may not have a corelational effect on radicalization. A further $21 \%$ of the respondents felt that identifying strangers may have no effect on the same end. However, over $69 \%$ of the respondents indicated that community vigilance might help expose strangers suspected of luring youth into violent extremism.

\section{Monitoring of Religious Activities and Physical Structures}

About $95 \%$ of the respondents felt that monitoring religious activities within Eastleigh was an extremely effective approach to reduce youth radicalization. In all interviews contacted during this study, there was unanimity that initial ignorance of religious teaching is a leading factor influencing the adoption of extreme religious views, especially among youth. Scanning for recurring youth problems such as rampant school dropout was cited by over $83 \%$ of the respondents as a very effective way of identifying and stopping youth from joining radicalized groups (Table 3). An interview with a principle of a high school within the Eastleigh area indicated that low educational standards in Eastleigh contribute to young people becoming more easily susceptible to manipulation and recruitment into extremist groups.

A considerable proportion of $92 \%$ of the respondents was of the view that disclosing clandestine occupation of structures, apartments, and housing units would by and large be an effective way through which the residents could help the authorities to check youth radicalization (Table 3). Indeed, interviews with three caretakers and one landlord disclosed that no much attention is given to apartment and guest house occupiers as long as they pay their rents and dues in time.

A key informant working with the directorate of criminal investigations described a scenario where al-Shabaab recruiters had rented a whole housing unit and turned it to a makeshift 'vocational youth training centre.' The Key informant added that the proprietor had offered to train young people on various skills and help them acquire employment in various countries within the Arab Peninsula. The training centre would recruit over 46 youth before within three months before a cub operator reported to the matter to the police. The cab driver had been engaged to transport some youth to Lamu. Interviews with three pastors of the different protestant churches suggested situations where law enforcement officers would join them during gospel crusades and vigil nights, either in uniform or in plainclothes depending on prevailing conditions. This was thought of to establish mutual engagements where parents, guardians, teachers, and religious leaders would comfortably identify indicators of youth radicalization at the preformative stages.

\section{Solutions to Youth Radicalization in Eastleigh}

Under this section, junior and senior police commanders, selected members of the local community, group, and religious leaders, were presented with the question, "What is your opinion would be the best solution to youth radicalization in Eastleigh?" This question statement attracted lengthy discussions from the community respondents. Responses were summarized to four themes; police operations, police-community partnerships, youth empowerment, and community intelligence.

\section{Police Operations}

Over $90 \%$ of the interviewees expressed wide reservations with police operations as a strategy of countering youth radicalization within Eastleigh. The general feeling was that the police operation exacerbates the radicalization processes. Indeed, a senior Muslim cleric observed thus,

"The youth have the perception that they are the target of politically motivated and ethnically-biased security practices and unjust judicial systems. Police operations are, therefore, often seen as part of the problem and tend to create further divisions between the state and citizens."

However, all senior police commanders interviewed expressed a contrary view on police operations. One of the commanders emphatically stated that the threat of terrorism requires a high presence of police patrols and operations to disrupt the terrorist network. An inference can there be drawn with some reasonable degree of certainty that 'hard' policing tactics can significantly undermine any attempts that police make to engage 
with the youth in Eastleigh. Indeed, from the literature review, previous research has it that trust and confidence in the police can be seriously undermined in situations where communities feel that they are over-policed (Bowling and Phillips, 2007).

\section{Police-Community Partnerships}

Over $80 \%$ of the interviewees identified policecommunity partnerships as a solution to the threat of radicalization within the Eastleigh area. However, they appeared apprehensive that such a partnership may only work if the threat of power differentials is adequately addressed. The main concern here was that community groups might not feel that they are actual partners in the policy process due to power imbalances between them and other partners such as the police and other government agencies. A quote from a Muslim youth who is a student at a local university illustrated this;

"In cases where there is a power imbalance between partners, it is important for those in positions of relative power to create spaces within which all partners are equals, included and respected. This is especially important in the context of police-community engagement as police officers are in positions of relative power over community members. Within a counterterrorism context that is based upon the involvement of communities, it is important to stress that partnership work is characterized by the absence of coercion - all parties are free to stop interacting as and when they choose."

This finding closely collaborates observations by Reiner (2007), who opines that partnership in counter-terrorism is more enhanced in situations where police respect the individuals they partner with. Such partnerships may be particularly difficult given that research exploring 'cop culture' has highlighted the often-inward-looking nature of police culture (Reiner, 2007). Therefore, it may be that in the context of counter-terrorism, it is the role of police to make the first move and to seek and act to bring about a relationship of trust.

\section{Counter Narratives and Youth Empowerment}

Religious and community leaders were recognized by both the law enforcement officials and residents as being capable of providing legitimate counternarratives and counselling to the target individuals and groups. Interviews with two sheikhs and an imam indicated that Muslim voices are best positioned to counter radical narratives within an authentic Islamic framework, while intelligently exerting pressure from within Muslim communities to moderate radical individuals and institution. Community police officers and local peace committees' leaders were mentioned as having the prowess to leverage religious, state, and non-state actors in developing community-led interventions with a view to addressing social alienation. An interviewee who was Muslim Imam was quoted;

"We should go to the Saudi Arabian way where the government pursues a community and family-level approach that focuses on radicalized individuals who have not yet taken violent actions. Once an individual is apprehended there, imams and religious clerics are involved in providing religious reeducation."

The impression created here is that local leadership, especially religious and administrative officials, should mobilize and engage both public and private foundations to initiate and facilitate communitybased capacity building community centres for the youth. Such programs were seen as being capable of fostering a sense of belonging and economic empowerment. In addition, the youth could be engaged in such activities as sporting and creative arts above providing them with access to mentors who preach socially responsible definitions of what it means to be a good Muslim based on local values. An emphasis was put on the effect that counternarrative programs be extended to institutions of learning, law enforcement agencies, security committees, and media.

\section{Community Intelligence}

Both police and community interviewees' opinion on the importance of information sharing was evident. However, there appeared to be a sharp difference in the management of information arising from community intelligence networks 
because police chiefs unanimously indicated that information on terrorism and radicalization was classified for national security purposes and, as such, feedback on police action concerning information originating from the locals remains limited or non-existent. Conversely, local community leaders noted that community intelligence could only be considered as an ample counter-radicalization approach if the police were willing enough to offer adequate and timely feedback while maintaining the principles of confidentiality and trust. Innes (2006) argue that low trust in the police can inhibit the willingness of individuals to pass community intelligence about a range of problems and issues, and a report by Edwards (2007) highlights the importance of high trust relationships between communities and the police for effective national security in the age of 'home-grown terrorism.'

A breakdown of police-community relations can have serious consequences for policing, and in the context of counter-terrorism, can halt the flow of vital information from communities (Hillyard, 1993; Hillyard, 2005). Therefore, it follows that in order to consider community intelligence as a radicalization prevention technique, the police have to build close and productive relationships with the citizens they serve. This way, officers are highly likely to have immediate and unfettered access to local neighbourhood information as it develops. Meaningful dialogue may require police officers to endeavouring to answer queries that communities have in relation to the scope of counter-terror powers and investigations and possible impacts on the local communities of Eastleigh.

\section{CONCLUSION}

An informed inference can be drawn to the effect that political, socioeconomic, and individual factors are key drivers of youth into violent extremism within Eastleigh. The diversity and dynamic nature of these factors present a situation whereby no single counter-radicalization approach can be said to adequately address the threat of youth radicalization in Eastleigh. It can further be stated that while it is true that the police are the most visible keepers of the law, they may not singlehandedly address the myriad upstream factors that drive youth to violent extremism. Indeed, the study established that engaging local communities in the prevention of radicalization within Eastleigh could be a key point of departure in the "war against terrorism.'

\section{ACKNOWLEDGMENTS}

The authors sincerely appreciated the efforts pumped in by colleagues who helped with the questionnaires and mobilized the recruitment of samples in their respective rural counties. The authors also extend great gratitude to the anonymous reviewers and editors for their helpful review and critical comments.

\section{REFERENCES}

Ali, A. (2009). Radicalization process in the horn of Africa-phases and relevant factors. African Affairs, 14(2), 11-20.

Allan, H., Glazzard, A., Jesperson, S. T., \& Sneha Reddy Winterbotham, E. (2015). Drivers of violent extremism: Hypotheses and literature review. Royal United Services Institute.

Aronson, S. L. (2011). United States Aid to Kenya: A Study on Regional Security and Counterterrorism Assistance Before and After 9/11. African Journal of Criminology \& Justice Studies, 5.

Botha, A. (2013). Assessing the vulnerability of Kenyan youths to radicalization and extremism. Institute for Security Studies Papers, 2013(245), 28-28.

Botha, A. (2014). Radicalization in Kenya. Recruitment to al-Shabaab and the Mombasa Republican Council. Institute for Security Studies Papers, 2014(265), 28-28.

Bowling, B., \& Phillips, C. (2007). Disproportionate and discriminatory: Reviewing the evidence on police stop and search. The Modern Law Review, 70(6), 936961.

Diani, M. \& McAdam, D. (2003). Social Movements and Networks: Relational Approaches to Collective Action. Oxford: Oxford University Press 
Dollard, J., Miller, N. E., Doob, L. W., Mowrer, O. H., \& Sears, R. R. (1939). Frustration and aggression. Yale University Press. Doi: $10.1037 / 10022-000$

Edwards, C. (2007). The activist police force. London: Demos.

Fearon, J. D., \& Laitin, D. D. (2003). Ethnicity, insurgency, and civil war. American political science review, 97(1), 75-90.

Guiora, A. N. (2008). Religious Extremism: A Fundamental Danger. South Texas Law Review, 50, 743.

Hillyard, P. (1993). Suspect community: people's experience of the Prevention of Terrorism Acts in Britain. Pluto Pr.

Hillyard, P. (2005). The "war on terror": Lessons from Ireland, Essays for civil liberties and democracy in Europe. European Civil Liberties Network.

Innes, M. (2006). Policing uncertainty: Countering terror through community intelligence and democratic policing. The Annals of the American Academy of Political and Social Science, 605(1), 222-241.

Kombo, D. K., \& Tromp, D. L. A. (2010). Proposal and Project Writing: An Introduction. Nairobi, KE: Pauline Publication Africa

Marchal, R. (2009). A tentative assessment of the Somali Harakat Al-Shabaab. Journal of Eastern African Studies, 3(3), 381-404.

Mogire, E., \& Mkutu Agade, K. (2011). Counterterrorism in Kenya. Journal of Contemporary African Studies, 29(4), 473-491.

NCPD. (2013). Kenya Population Situation Analysis. Nairobi, KE: National Council for Population and Development (NCPD).

Otiso, K. (2009). Kenya in the crosshairs of global terrorism: fighting terrorism at the periphery. Kenya Studies Review, 1(1), 107132.
Reiner, R. (2007). The Politics of the Police (3rd edition). Oxford, UK: Oxford University Press.

Rogers, M. B., Loewenthal, K. M., Lewis, C. A., Amlôt, R., Cinnirella, M., \& Ansari, H. (2007). The role of religious fundamentalism in terrorist violence: A social psychological analysis. International Review of Psychiatry, 19(3), 253-262.

Rosand, E., Millar, A., \& Ipe, J. (2007). Enhancing counter-terrorism in Eastern Africa. African Security Review, 18(2), 12-25.

Schmid, A. P. (2013). Radicalisation, deradicalisation, counter-radicalisation: A conceptual discussion and literature review. ICCT Research Paper, 97(1), 22.

UNHCR \& Danish Refugee Council. (2012). Promoting Livelihoods to Build the SelfReliance of Urban Refugees in Nairobi. Nairobi, KE: United Nations High Commissioner for Refugees and the Danish Refugee Council.

Vittori, J., Bremer, K., \& Vittori, P. (2009). Islam in Tanzania and Kenya: Ally or Threat in the War on Terror?. Studies in Conflict \& Terrorism, 32(12), 1075-1099. 